\title{
Metodologias ativas como estratégia pedagógica para a aplicação da arqueologia da arquitetura na restauração arquitetônica no Brasil
}

\section{Active methodologies as a pedagogical strategy for applying archaeology of architecture in architectural restoration in Brazil}

\author{
Metodologías activas como estrategia pedagógica para la aplicación de la \\ arqueología de la arquitectura en la restauración arquitectónica en Brasil
}

Ton Ferreira ${ }^{1}$

Universidade Federal de Sergipe, Departamento de Arqueologia

Pedro Freitas ${ }^{2}$

Universidade Federal de Sergipe, Departamento de Arquitetura e Urbanismo

\begin{abstract}
RESUMO
As abordagens metodológicas da arqueologia brasileira sobre a arquitetura sempre priorizaram as informações acerca das estruturas soterradas e a exumação do espólio a elas associadas. Durante o programa de recuperação de cidades históricas, denominado Monumenta, a falta de metodologias para o reconhecimento e a análise da materialidade construtiva histórica, aliada a um acelerado desenvolvimento imobiliário, ampliou o desaparecimento de parte do testemunho do hibridismo cultural do que hoje chamamos Brasil. O objetivo principal do presente artigo é demonstrar o processo de elaboração das oficinas que resultou num desenho metodológico para sanar as lacunas da atividade arqueológica brasileira no restauro da edificação histórica. Após análise das limitações das abordagens da arqueologia da arquitetura (AA) para pensar as edificações locais, aplicamos "metodologias ativas de ensino" para alunos de graduação em arqueologia e arquitetura, da Universidade Federal de Sergipe. Os resultados das intervenções nas ruínas da "Casa n. 3" em Laranjeiras demonstram que a aplicação da AA em contexto brasileiro requer adaptações, mas ainda se constitui em um eficiente instrumento para identificação e valorização da arquitetura histórica em processos de desaparecimento.
\end{abstract}

Palavras-chave: Laranjeiras-Sergipe; ensino interdisciplinar; metodologias ativas; ruínas urbanas.

\begin{abstract}
Methodological approaches of Brazilian archaeology to architecture have always focused on buried structures and exhumation of their assets. Within the historic cities recovery program, also known as Monumenta, the lack of methodologies for assessing historical constructive materiality, and the accelerated real estate development increased the disappearance of part of the Brazilian cultural hybridism. Thus, the present study aims to demonstrate a workshop practical process that poses a methodological design to fill in the gaps in the Brazilian archaeological activity with the restoration of historic buildings. After evaluating the limits of the Archaeology of Architecture (AA) approaches to local objects, active teaching-learning methodologies were applied to pedagogical workshops for archaeology and architecture undergraduate students at the Federal University of Sergipe. The results of the interventions in the ruins of "Casa n. 3 " in Laranjeiras city demonstrated that AA application requires adaptations when considering a Brazilian context; however, it is still an efficient tool for identifying and valuing historical architecture in disappearance processes.
\end{abstract}

Keywords: Laranjeiras-Sergipe; interdisciplinary teaching; active methodologies; urban ruins word.

tonferreira@ufs.br / ORCID iD: https://orcid.org/0000-0002-9120-3369

pedromurilo@ufs.br / ORCID iD: https://orcid.org/0000-0002-8563-6993 


\section{RESUMEN}

Los enfoques metodológicos de la arqueología brasileña en la arquitectura siempre han priorizado la información sobre las estructuras enterradas y la exhumación de los objetos. Durante el programa para la recuperación de ciudades históricas, llamado Monumenta, la falta de metodologías para el reconocimiento y análisis de la materialidad constructiva histórica, junto con el desarrollo inmobiliario acelerado, conllevó a la desaparición de parte del testimonio de la hibridación cultural de lo que ahora llamamos Brasil. El propósito de este artículo es mostrar el proceso práctico de los talleres que resultaron en un diseño metodológico para llenar el vacío en la actividad arqueológica brasileña con la restauración del edificio histórico. Después de analizar las limitaciones de los enfoques de arqueología de la arquitectura (AA) sobre los objetos locales, aplicamos "metodologías de enseñanza activa" a talleres pedagógicos para estudiantes universitarios de arqueología y arquitectura en la Universidad Federal de Sergipe. Los resultados de las intervenciones en las ruinas de "Casa n. 3" en Laranjeiras demuestran que la aplicación de AA en un contexto brasileño requiere adaptaciones, pero sigue siendo un instrumento eficiente para identificar y valorar la arquitectura histórica en los procesos de desaparición.

Palabras clave: Laranjeiras-Sergipe; enseñanza interdisciplinar; metodologías activas; ruinas urbanas.

Received: 27-09-2019. Accepted: 04-05-2020. Published online: 29-05-2020

\section{Citation / Cómo citar este artículo}

Ferreira, T. y Freitas, P. 2020: "Metodologias ativas como estratégia pedagógica para a aplicação da arqueologia da arquitetura na restauração arquitetônica no Brasil", Arqueología de la Arquitectura, 17: e107. https://doi.org/10.3989/arq.arqt.2020.015

Copyright: (C) CSIC, 2020. ( ) UPV/EHU Press, 2020. This is an open-access article distributed under the terms of the Creative Commons Attribution 4.0 International (CC BY 4.0) License.

\section{INTRODUÇÃO}

Durante as duas últimas décadas, o Brasil passou por um acelerado processo de revitalização de diversos centros históricos. Os anos de crescimento econômico, antes do estopim da última crise financeira, revelaram a nossa dificuldade em lidar com o restauro arquitetônico como um processo interdisciplinar de construção de conhecimento sobre o nosso passado. Por um lado, ficou evidente a lacuna metodológica da arqueologia brasileira para registrar e analisar, sistematicamente, a cultura material da edificação histórica; por outro, os frágeis levantamentos arquitetônicos vinculados à ausência do labor do historiador resultaram numa série de monumentos ditos "restaurados" cujas histórias ficaram reduzidas a ruínas.

Tal problemática nos levou a buscar bases metodológicas para pensar na atuação do arqueólogo junto ao projeto de restauro para o contexto brasileiro. $\mathrm{O}$ encontro com a arqueologia da arquitetura (AA), através da especialização na referida área, na Politécnica de Madrid, e posterior construção de uma tese, na Autônoma de Madrid, fez-nos refletir sobre as especificidades do contexto brasileiro. Naquele momento, tínhamos a percepção de que expor a problemática e demonstrar os logros de um novo olhar sobre a atuação do arqueólogo, no que diz respeito à edificação histórica, fosse suficiente para mudar nosso trato com a materialidade edificada.

Ao regressar para o Brasil entendemos que uma mudança na práxis implicava alterar critérios construídos pelo Instituto do Patrimônio Histórico e Artístico Nacional. Implicava ainda profundas mudanças na estruturação e atuação das empresas de arquitetura, já consolidadas no mercado há décadas. A problemática mais urgente nessa discussão reside no desaparecimento gradual da materialidade construtiva que testemunha um processo complexo de hibridismos culturais na construção do que hoje chamamos Brasil. Nesse contexto, uma solução possível seria a criação de estratégias pedagógicas que possibilitassem uma mudança de perspectiva na formação dos futuros arquitetos e arqueólogos.

Dessa forma, desenhamos o projeto "Laranjeiras sítio-escola" objetivando a introdução da AA, através das metodologias ativas de ensino, em oficinas práticas para alunos de arqueologia e arquitetura, simultaneamente. A questão central do presente artigo é demonstrar o processo que resultou num desenho metodológico para atuação arqueológica no restauro da edificação histórica local. Secundariamente, trazemos uma discussão sobre o desenvolvimento da arqueologia brasileira, que pode justificar a tardia introdução da AA voltada para o estudo da cultura material construtiva e, consequentemente, a falta de bases sistemáticas para atuar na restauração arquitetônica.

Do ponto de vista da arqueologia brasileira, o objeto arquitetura sempre esteve classificado nos currículos da chamada arqueologia histórica. A divisão entre arqueologia histórica e pré-histórica, presente em toda a América, foi uma herança estadunidense e está intimamente ligada à ideia do nativo integrado à história natural do 
território. A partir da chegada do colonizador, inaugurou-se um novo processo histórico, entendido como o início de sua conformação nacional (Johnson 1999), dando margem para que as culturas do novo mundo fossem excluídas e pouco valoradas dentro das narrativas históricas do espaço americano. Trata-se de uma ordenação disciplinar que resultou também na estruturação acadêmica.

A investigação sobre as abordagens da arqueologia brasileira para a edificação histórica foi fundamental para entendermos a ausência de metodologias para o registro de estratos verticais. Em uma síntese da teoria arqueológica e seus enfoques na arqueologia histórica (Santos 2011), realizada sobre a bibliografia dos principais autores brasileiros, ficou evidente que os ditames teóricos arqueológicos assumidos pelos principais centros formadores de profissionais no país foram responsáveis por um maior ou menor distanciamento do objeto arquitetura. Nesse sentido, nos enfoques histórico-culturalista e processual, as abordagens metodológicas estiveram quase sempre vinculadas às escavações de solos, seja no interior ou exterior das edificações. A percepção e o estudo da materialidade construtiva se limitavam a estruturas de fundações, sobreposições de pisos, aterros e todo o arcabouço construtivo presente até a cota zero. As parcas abordagens sobre os corpos de estruturas "históricas" estiveram sempre relegadas à busca de portas e janelas fechadas no decorrer da sua evolução construtiva, a depender da sensibilidade do arqueólogo caso a caso, sem, portanto, constituir um arcabouço metodológico sistemático para o entendimento da materialidade construtiva vertical (Santos 2011).

A partir da década de 1990, é notória a crítica dos arqueólogos brasileiros à arqueologia realizada no país. A produção era classificada como pouco teórica e fechada aos postulados vigentes nos grandes centros de produção científica. O período que coincide com o aumento significativo da arqueologia histórica no país foi marcado pela inclusão da chamada arqueologia pós-processual e uma dura crítica aos estudos arqueográficos e arqueométricos da cultura material (Barreto 1999). Durante a década de 2000, a ideia da arqueologia pós-processual se firmou como pensamento da renovação da arqueologia brasileira. Foi nesse contexto que o objeto arquitetura voltou a ser inserido na discussão da arqueologia histórica, a partir da tese de doutorado de Andres Zarankin, buscando caracterizar, através das análises espaciais arquitetônicas, os mecanismos de poder e controle nas edificações escolares de Buenos Aires do século XX (Zarankin 2001).
No entanto, a falta de metodologias sistemáticas para o estudo das construções, no âmbito da prática arqueológica brasileira, somente ficou evidente no cenário nacional com os embates gerados durante o último grande programa de "revitalização do patrimônio histórico". O programa Monumenta (Brasil 2006) ignorou a arquitetura como resultante de processos sociais que determinaram alterações físicas de interesse histórico e documental.

O programa, cuja fase de estruturação ocorreu entre os anos de 1995 e 2000, possuía como princípio as ideias defendidas na Conferência de Quito, em 1967. A partir dessa conferência, instituições como o Banco Interamericano de Desenvolvimento (BID) e a Organização das Nações Unidas para a Educação, a Ciência e a Cultura (UNESCO) passaram a apoiar, em diversos países da América Latina, projetos que tivessem como objetivo promover a conservação e o estudo do patrimônio cultural compatível com desenvolvimento econômico do continente. As ações do Monumenta atingiram 26 cidades, localizadas em 17 Estados da federação brasileira. A maior parte das ações eram realizadas em conjuntos históricos ou em monumentos isolados, como museus, igrejas, fortificações, casas de câmara e cadeia, palacetes, conjuntos escultóricos, conventos, fortes, ruas, logradouros, espaços públicos e privados em todas as áreas tombadas pela União (Brasil 2006).

Com o aumento das ações do programa, a problemática acerca da ausência de uma análise mais acurada dos processos sociais tomou proporções nacionais deixando evidente a crescente agressividade dos projetos - frequentemente associados à modernização de infraestruturas e ao desenvolvimento turístico -, cuja celeridade tendia a ignorar a historicidade geral das construções, também no campo comum de interesse dos arqueólogos, o solo. E, não obstante os discursos de arqueólogos que ocupavam postos de trabalhos nos institutos e demais órgãos de preservação do patrimônio sinalizassem a necessidade de maior participação da arqueologia em projetos de revitalização, tais alertas foram frequentemente ignorados (Costa 2013). Como resultado, ao lado da necessidade de ampliar a abordagem interdisciplinar de metodologias de pesquisa arqueológica em edifícios históricos, expunha-se a baixa consideração da arqueologia brasileira de interagir, com instrumentos adequados, a favor da interpretação histórica das construções.

Por outro lado, aos arquitetos não se colocavam nem mesmo tais questões. De fato, para a Arquitetura, o reconhecimento do patrimônio nacional brasileiro vinculado ao ideário moderno - de narrativa progressista e de 
desenvolvimento do país de modo unitário - era um critério suficiente para a constituição do campo da preservação arquitetônica brasileira, baseada no estudo de exemplares coloniais monumentais (Fonseca 2005). A manutenção de práticas de restituição estilística ao longo do século XX, ainda que essas tenham sido responsáveis pelo salvamento de muitos edifícios importantes que se encontravam arruinados, enfraqueceu no país, também entre os arquitetos, a elaboração de metodologias de estudo de edifícios que observassem sua natureza estratigráfica. $\mathrm{O}$ estudo do quadro construído antigo (sempre colonial português, por princípio) limitou-se à identificação exclusiva de técnicas e elementos construtivos tradicionais, quando úteis à projetação da nova edificação, anulando a percepção das marcas do tempo no corpo das edificações.

A "arquitetura de pedra e cal" e a "arquitetura da taipa" eram reconhecidas como signos da identidade da arquitetura brasileira, não interessava exponenciar as diferenças construtivas de um vasto território como o Brasil. Era frequente a homogeneização de vários "tipos" que pudessem explicar a tradição construtiva "portuguesa" em território brasileiro. Tais parâmetros, que se difundiram a partir do discurso historiográfico moderno e positivamente construíram repertórios ainda hoje fundamentais para a compreensão de parte significativa da arquitetura histórica brasileira (Corona e Lemos 1973), também reduziram o alcance e a operacionalização da restauração brasileira às tendências internacionais de análise crítico-construtiva da arquitetura e fundamental disciplina que combina, no exercício projetual, o estudo da materialidade histórica para o desenvolvimento de critérios de intervenção e, de modo mais amplo, à valorização do contexto e da preexistência na elaboração do projeto arquitetônico (Carbonara 2005).

Portanto, em que medida pode-se falar em AA no Brasil, visto que, de modo quase especular entre arqueólogos e arquitetos, é evidente a ausência de capacitação profissional para a interpretação da materialidade histórica das construções? Caberia examinarmos, ainda que sucintamente, como ela tem sido exercida.

\section{ABORDAGENS ARQUEOLÓGICAS NA RESTAURAÇÃO ARQUITETÔNICA BRASILEIRA}

A maior parte dos primeiros trabalhos de arqueologia histórica foram realizados em intervenções para restaurações arquitetônicas. A partir dos anos 1970, o Instituto do Patrimônio Histórico e Artístico Nacional (IPHAN) buscou revisar suas bases metodológicas e agregar, por via do estudo da materialidade, maior valor histórico aos monumentos por ele tombados ${ }^{3}$. No entanto, essa aproximação entre arqueologia e arquitetura coincide com os anseios por uma arqueologia mais interpretativa, fugindo das bases histórico-culturalistas e distanciando-se cada vez mais de abordagens cuja metodologia priorizasse a materialidade como sinônimo de evolução.

Os trabalhos desenvolvidos nesses primeiros momentos da disciplina no Brasil buscavam a identificação de estruturas arquitetônicas soterradas e o resgate dos artefatos nas áreas internas e externas das edificações. $\mathrm{O}$ resultado quase sempre terminava em relatórios técnicos arqueológicos de identificação de materiais e estruturas. Em alguns casos, as estruturas arquitetônicas evidenciadas, quase sempre pertencentes a edifícios anteriores ou mesmo a modificações do edifício em processo de restauro, eram musealizadas e integradas à proposta final do restauro.

A ideia de construir estudos mais aprofundados dos materiais construtivos ou mesmo intensificar análises estratigráficas sistemáticas das paredes não fazia parte das abordagens arqueológicas. Os arqueólogos se limitavam a realizar faixas de escavações de rebocos, deixando nua a parede em seu material estrutural, quase sempre em busca de portas e janelas cegadas. Por isso, muitas vezes, em pouco diferiam do desmonte realizado pelos pedreiros responsáveis pela obra de restauração.

Certamente, uma das características marcantes dessas primeiras intervenções no Brasil, as quais se perpetuam até a problemática atual e advinda do embate entre arquitetos restauradores e arqueólogos, é a incapacidade do arqueólogo de "olhar para cima", isto é, de enxergar as paredes do edifício como continuidade dos estratos do solo. Por outro lado, os arquitetos se sentiam cômodos com tal perspectiva, uma vez que podiam considerar um edifício "sem raízes", dando margem a

\footnotetext{
3 Em texto que objetivava revisar percurso da disciplina no Brasil, Tânia Lima ressaltava, já em 1993, que, até o início da década de 1980, diversos trabalhos da arqueologia em restaurações arquitetônicas haviam sido conduzidos, quase todos, em parceria com o IPHAN: citam-se as "Escavações nas Reduções jesuítas do Rio Grande do Sul (repassadas à Universidade); no Paço Imperial, no Rio de Janeiro; na Casa da Fundição do Ouro de Goiás; no antigo cais da Praça XV, no Rio de Janeiro (repassada ao município); na Casa dos Pilões, no Jardim Botânico do Rio de janeiro (executada pela 6a DR); em Vila Flor, no Rio Grande do Norte (repassada à Universidade); na Praça do Pelourinho, no centro histórico de Salvador; nas fortificações de Santa Catarina. Prospecções na Casa de Banho de D. João VI, no Rio de Janeiro; em Tiradentes, Minas Gerais; no centro histórico de Alcântara, Maranhão; nas dependências do Museu Histórico Nacional, no Rio de Janeiro" (Lima 1993: 228). No nordeste brasileiro, podemos aferir que o maior número de trabalhos nesse primeiro momento foi conduzido pelo arqueólogo Marcos Albuquerque.
} 
intervenções que resultassem em formas estilisticamente homogeneizadas.

Acreditamos que esse olhar dicotômico se deva à fragilidade das discussões sobre métodos e técnicas das abordagens arqueológicas desenvolvidas no Brasil. A introdução de metodologias ocorreu por duas vias: pelas missões estadunidense (a partir da década de 1950, com métodos extensivos, escavações por camadas artificiais objetivando a identificação de sítios arqueológicos em todo o território) e francesa (a partir de 1960, com foco intensivo sobre o sítio, as decapagens e as escavações por camadas naturais de ampla superfície, objetivando conhecer profundamente o sítio estudado; Barreto 1999).

Em maior ou menor escala, individualmente ou mesclados, tais métodos continuam sendo usados para todos os sítios arqueológicos brasileiros, inclusive para os sítios históricos urbanos. Nesse sentido, as discussões sobre uma estratigrafia arqueológica, em detrimento da geológica para pensar os contextos urbanos, nunca foram inseridas na arqueologia brasileira. Os postulados de Harris, que abriram caminho para a construção da AA, costumam ser criticados, mas nunca foram utilizados e discutidos à luz das necessidades do contexto brasileiro, o que explicaria a dificuldade de lidar com as unidades estratigráficas verticais e, portanto, com a sistematização da cultura material da edificação histórica (Villagran 2010; Araujo 2011).

Uma das intervenções pioneiras da arqueologia na restauração arquitetônica foi conduzida no final da década de 1970, por Marcos Albuquerque, professor da Universidade Federal de Pernambuco (UFPE). Os trabalhos faziam parte da política de preservação iniciada pelo IPHAN após aprovação da Lei de Defesa do Patrimônio Arqueológico (Brasil 1961). O próprio IPHAN era executor e os trabalhos desenvolvidos pelo arqueólogo teriam a função de "pôr em evidência novos dados que complementassem as pesquisas históricas e arquitetônicas já realizadas" e "poder obter maiores subsídios que possibilitassem uma restauração do monumento em bases mais sólidas" (Albuquerque 1980: 89).

A atividade foi desenvolvida na igreja quinhentista de Nossa Senhora da Divina Graça, em Olinda. Em termos metodológicos, o referido autor afirma ter realizado uma escavação completa de toda a igreja, salvo em partes que comprometiam a sua estrutura, dado que seu estudo havia começado antes de qualquer desmonte que precedera a fase de efetivação do restauro. Percebe-se a liberdade que possuíam os poucos arqueólogos nesses primeiros momentos de intervenção arqueológica no restauro que, contudo, chocava-se diretamente com a possibilidade de realização de estudos prévios e não-destrutivos, além de tolher possibilidades de diálogos verdadeiramente interdisciplinares.

Ainda nessa perspectiva, em publicação de 1992, o autor deixa clara a sua inquietude em relação às críticas dos arqueólogos que reivindicavam uma arqueologia teoricamente orientada, fosse pelo viés processual ou pós-processual. No entanto, segundo sua ótica como pesquisador, era necessário refletir sobre a dicotomia de uma arqueologia histórica cognitiva, dando a entender que os novos discursos teóricos pareciam ir de encontro com sua prática arqueológica. Nesse sentido, Albuquerque, pioneiro nos estudos arqueológicos junto ao restauro, ressaltava a necessidade de a arqueologia histórica buscar novos parâmetros metodológicos para suas intervenções (Albuquerque 1992), ainda que isso não refletisse em mudanças efetivas em suas metodologias de investigação com alto grau de destruição de rebocos históricos.

As primeiras aproximações entre a arqueologia e a arquitetura, em território brasileiro, podem ser vislumbradas de fato somente a partir dos estudos realizados no início dos anos 1990, pela arquiteta Regina Tirello, restauradora da Universidade de São Paulo (USP) e atualmente professora da Universidade Estadual de Campinas (Unicamp). Seu campo de interesse, ao contrário de Albuquerque, partia da exigência pela conservação de pinturas murais sobre rebocos antigos, estimulada pelo estudo da ornamentação de edifícios ecléticos de São Paulo por historiadores da arquitetura, como Nestor Goulart Reis Filho (Camargo 2015). Reis Filho era professor responsável, já em 1974, pela coordenação do primeiro curso de especialização em restauração arquitetônica no Brasil, realizado na Faculdade de Arquitetura e Urbanismo (FAU), embrião do atual Mestrado Profissional em Conservação e Restauração de Monumentos e Núcleos Históricos, da Universidade Federal da Bahia (CECRE/UFBA). Seu interesse pela análise pormenorizada da arquitetura burguesa paulista deu margem à formação de arquitetos restauradores naqueles anos, permitindo a ampliação de pesquisas sobre o patrimônio cultural de São Paulo datado do final do século XIX, constantemente ameaçado pela sua rápida expansão metropolitana.

Apenas no início de década de 1990, por meio da criação de um canteiro-escola de restauração de bens integrados no âmbito da Comissão do Patrimônio Cultural da USP (atual Centro de Preservação Cultural), Regina 
Tirello tornou-se responsável, entre outros, pela introdução e popularização no país das chamadas "prospecções arqueológicas de superfície" (Tirello 1999). Para além da descoberta de diversas camadas de tinta aplicadas sobre a superfície de um mesmo ambiente, tais prospecções eram capazes de revelar, de modo controlado e pela análise dos tipos ornamentais e ciclos decorativos, processos de alteração ambiental pari passu à caracterização dos materiais artísticos aplicados (Tirello 2002).

É notório o quanto, ao longo das primeiras décadas do século XXI, estudos publicados pela arquiteta, entre análises preparatórias à restauração de ambientes em edifícios de interesse da Comissão (a exemplo da Vila Penteado e da Casa de Dona Yayá, ambos em São Paulo), contribuíram para o estudo da cultura material paulista, de tecnologia construtiva associada à imigração europeia recente. Nessa imigração, inclusive, destaca-se a proposição de um método baseado em "indicadores temporais", com filiações mais diretas ao campo da AA (Tirello 2007), com o objetivo de oferecer informações renovadas e procedimentos de análise crítica sobre realidades construtivas pouquíssimo documentadas. Contudo, também cabe lembrar que a experiência se vinculou quase exclusivamente ao ainda parco desenvolvimento da ciência da conservação no país, que, apesar de fazê-lo apoiando-se em metodologias arqueológicas, teve pouco diálogo efetivo com os arqueólogos, transformando-se em experiências isoladas.

$\mathrm{Na}$ tentativa de sanar tal lacuna, o IPHAN publicou o Manual de Arqueologia Histórica em Projetos de Restauração no ano de 2002. "Seu objetivo é atender exigências de orientação técnica na gestão dos projetos de restauração/conservação dos bens imóveis tombados sob tutela federal. Tem ainda a intenção de suprir a necessidade de estabelecimento de procedimentos padrões, a serem adotados pelo IPHAN" (Najjar 2002: 3).

A autora do referido manual, a arqueóloga Rosana Najjar, trata das intervenções arqueológicas no restauro brasileiro também como fazendo parte da "arqueologia da arquitetura", mas com forte matriz teórica histórico-culturalista, ou seja, onde o papel do arqueólogo seria o de preencher as lacunas historiográficas. Para ela, mesmo um historiador com noções de arqueologia poderia conduzir os trabalhos de campo (Najjar 2002).

O pequeno tópico que trata historicamente o tema, no manual, finaliza com uma problemática assertiva sobre como, segundo a autora, a arqueologia pós-processualista vislumbra o monumento como um grande artefato, com base em declarações, de 1995, do arqueólogo
Russell Handsman: “A Arqueologia Pós-Processualista propõe que a edificação seja estudada como se fosse, ela própria, um super objeto - um superartefato - e não meramente onde estão localizados os objetos. Desta maneira, a própria edificação ganha "vida"" (Najjar 2002: 10).

Apesar da autora evocar o termo arqueologia da arquitetura, o manual não apresenta nenhum aspecto metodológico ou teórico da chamada AA desenvolvida na Europa. O manual é basicamente uma síntese das abordagens já referenciadas anteriormente, sondagens em solo e desmonte de paredes, buscando deixar evidentes possíveis mudanças e estruturas, sem construir nenhuma análise sistemática sobre os parâmentos ou informações construtivas que se inserissem nos estudos prévios solicitados pelas cartas patrimoniais internacionais.

Também recorrendo à nomenclatura arqueologia da arquitetura, os trabalhos de Zarankin podem ser classificados no marco teórico da chamada arqueologia histórica pós-processual. Seus trabalhos constituem uma rica influência da filosofia e da sociologia europeia, a exemplo de pensadores como Foucalt e Bourdieu, para sustentar a narrativa de identificação de arquiteturas que denotam relações de controle e poder, no âmbito das sociedades moderna. Como suporte metodológico, suas análises são orientadas pelas formas, funções e organização espacial arquitetônica, baseadas em autores anglo-saxões como como Hillier e Hanson (1984) (Zarankin 2001: 119). Suas análises tem sido de grande importância para trazer a discussão contemporânea sobre a arquitetura do terror e do poder das ditaduras militares do século XX na América Latina (Zarankin e Niro 2008). Apesar da importante contribuição teórica de Zarankin, sua abordagem metodológica não chegou a favorecer a discussão sobre o desparecimento da arquitetura histórica brasileira ou mesmo sobre o aporte da arqueologia no processo de restauro.

\section{ARQUEOLOGIA DA ARQUITETURA E RESTAURAÇÃO NO BRASIL: ATUALIDADE DO DEBATE}

A arqueologia da arquitetura é uma disciplina que se configurou como um importante instrumento metodológico para o processo de restauro do patrimônio edificado. Esse novo método possibilitou construir percepções renovadas sobre edifícios tradicionalmente estudados, revisando esquemas estilísticos que se constituíam nas bases principais para a formação de qualquer arquiteto 
restaurador. Também, o reencontro com a materialidade através da sistematização dos dados estratigráficos colocou em evidência a fragilidade de conhecimento produzido ao longo de décadas pela disciplina, levando arquitetos europeus, sobretudo italianos e espanhóis, a reconhecer a importância da "marginalizada" arqueologia para a restauração arquitetônica nos idos das décadas de 1980 e 1990 (Doglioni 1988).

Ainda que tal reconhecimento não tenha significado, inicialmente, uma abertura do campo da restauração arquitetônica para os arqueólogos, tal metodologia foi absorvida pelos arquitetos e aplicada "na sua área de trabalho" como uma inovação, como um método eficiente na sistematização de dados antes perdidos ou irreconhecíveis, a partir de projeções estilísticas de estudos vinculados a outros campos do conhecimento, entre eles e principalmente, a história da arte. A arqueologia da arquitetura, como campo integrado à restauração arquitetônica, transformou-se num método cada vez mais eficiente, que, com o apoio da ciência da conservação, permitiu a construção e a revisão de hipóteses sobre a história das construções e ampliou a aplicação de variadas técnicas de análise não destrutiva e práticas de reconhecimento material. Seu objetivo vinculado à construção de critérios de projeto, consolidou conhecimentos específicos sobre técnicas construtivas e, sobretudo, valorizou a importância da tomada e da documentação de dados físicos (Mileto e Vegas 2003).

Apesar do claro avanço das pesquisas atuais da AA no restauro, pensar sua transferência metodológica para o contexto brasileiro requer uma série de ressalvas inerentes às especificidades da arquitetura local (considerando, sobretudo, sua ampla variedade ainda não estudada). $\mathrm{O}$ fato de a disciplina ter experimentado um amplo desenvolvimento em edifícios medievais mediterrâneos dotou-a de um robusto vocabulário técnico associado à evolução construtiva e às especificidades da construção em pedra, com exceções pontuais aos estudos de caso no sul da Espanha e no nordeste da Itália (Mannoni e Milanese 1988).

Dessa forma, já de partida, sua vinculação ao território nacional requer a construção de novas bases sobre a evolução construtiva da arquitetura vernácula brasileira. Essa demanda diz respeito, sobretudo, a repensar a já mencionada valorização da arquitetura de origem portuguesa em detrimento de outras culturas, como africanas e indígenas, cujas características construtivas foram pouco estudadas ou simplesmente negadas na tentativa de forjar uma identidade brasileira homogênea e livre de contradições.

Se ainda considerarmos o problema essencial de formação de arquitetos e arqueólogos, como já colocamos, dificuldades também são ponderáveis no âmbito do ensino, sobretudo nos currículos de arquitetura e urbanismo e arqueologia, no que tange à compreensão da finalidade da AA para o exercício do projeto (incluindo a colocação do projeto de restauro no cômpito geral da formação do arquiteto). Entendemos que a aplicação da arqueologia da arquitetura no Brasil ainda tem carecido de pautas renovadas, em compromisso com a construção de novas narrativas sobre a história das construções brasileiras, ampliada pelas potencialidades da leitura tridimensional da estratigrafia murária, é justamente no momento mais básico da formação de arquitetos e arqueólogos que estão ainda abertos o interesse e a curiosidade para a promoção de diálogos mais efetivos a fim de atenuar os vários impasses que poderão advir de futuras relações profissionais.

Com base nessas premissas, e na vivência como docentes da Universidade Federal de Sergipe nos cursos de arquitetura e urbanismo e arqueologia, vislumbramos um desafio ainda maior: ampliar o escopo curricular de alunos sem, necessariamente, depender das difíceis alterações de grades curriculares de ambos os cursos. Projetos de extensão e oficinas surgiram, então, como alternativas às atividades disciplinares, que poderiam se constituir em protótipos de experimentação de novos processos de ensino-aprendizado ${ }^{4}$. Buscando-se alternativas efetivas de contato com a realidade da problemática patrimonial vivida na cidade de Laranjeiras, sede de ambos os cursos, as chamadas "metodologias ativas" poderiam oferecer respostas para tais demandas, bem como estimular a autonomia e o trabalho em equipe entre alunos envolvidos no processo de aprendizagem da arqueologia da arquitetura, respeitando as especificidades locais.

Considerando que os resultados apresentados não constituem um estudo de caso acabado, interessa-nos aqui o processo em si como mediador para o entendimento da AA e suas possíveis contribuições para as necessidades atuais das pesquisas arqueológicas vinculadas à prática do restauro e ao registro sistemático de uma importante parcela da edificação histórica em vias de desaparecimento.

\footnotetext{
4 Foram espaço de aplicação de oficinas em AA, na Universidade Federal de Sergipe, as disciplinas: Prática de Campo II, do curso de Arqueologia, semestre 2018.2, com o professor responsável Ton Ferreira, e Tópicos Especiais em Plenejamento I: Projeto de Intervenção no Patrimônio Arquitetônico e Urbano, do curso de Arquitetura e Urbanismo, semestre 2019.1, com o professor responsável Pedro Murilo Gonçalves de Freitas.
} 


\section{O ENSINO DA ARQUEOLOGIA DA ARQUITETURA ATRAVÉS DE METODOLOGIAS ATIVAS: A "CASA N. 3" EM LARANJEIRAS, SERGIPE}

A proposta de práticas integradas entre os cursos de arquitetura e urbanismo e arqueologia tem seu ponto forte na solução das dicotomias entre teoria e prática no ensino profissional, pois a construção da estrutura curricular parte da conjugação entre ensino e trabalho (Davini 2009). Partindo-se de situações reais, complementares à realidade social na qual o aluno está inserido, modificam-se as relações padrões entre professor e aluno, permitindo a revisão das estruturas de poder existentes entre quem "detém o conhecimento" e quem o deve "receber" passivamente.

Proporciona-se, assim, ao estudante a oportunidade de vislumbrar diversos problemas reais da profissão, também contribuindo para mudanças em âmbito profissional, mesmo antes do aluno se inserir completamente no mercado de trabalho. Com o incentivo nos processos de formação, evitam-se as corriqueiras frustrações quanto ao impacto entre as exigências do currículo descontextualizado e sua utilidade futura.

Os chamados "métodos ativos" de ensino-aprendizagem constituem uma das maiores mudanças nas propostas pedagógicas, pois a necessidade de integrar o ensino à realidade do trabalho requer o planejamento e a construção de atividades que estejam consonantes com os serviços vinculados à profissão. $\mathrm{O}$ contato com a realidade profissional levará o estudante à reflexão de problemas concretos, podendo gerar novos conhecimentos e soluções novas para a área de atuação (Berbel 2014). Tal perspectiva pode ser um passo para a construção de novas práticas profissionais e construção de novas realidades (e mentalidades) para o contexto vivido.

Os princípios dos métodos ativos de ensino englobam toda a dinâmica pedagógica. O primeiro deles é entender o aluno como centro do processo de ensino-aprendizagem, em lugar da figura do professor expositor.O professor, por sua vez, é percebido como agente facilitador, mediando o processo de aprendizagem, facilitando o acesso ao conhecimento e instigando o aluno nessa busca. Assim, o estímulo à autonomia (do aluno) é um segundo princípio orientador da abordagem ativa. $\mathrm{O}$ aprendizado se consolida a partir do interesse pessoal, de escolhas que façam sentido para o indivíduo, exercitando uma liberdade fundamental para a vida profissional e pessoal.

Em décadas anteriores, o pensador Paulo Freire (2002), educador de renome no Ocidente, já havia alertado para o problema de os métodos tradicionais de ensino não possibilitarem o estímulo à autonomia dos alunos. Nessa perspectiva, a problematização da realidade e a reflexão são fundamentais para o exercício da autonomia. Para tanto, pautam-se problemas que cercam a dinâmica da profissão e vida sociocultural, gerando-se uma rede que permite valorizar o trabalho em equipe e a crítica a todo o processo de ensino. A promoção da autonomia descontrói o arranjo da sala de aula tradicional que impede o aluno de interagir e exercitar a reflexão e o diálogo. A partir dessa perspectiva libertadora - uma vez que produz emancipação -, fundamenta-se o desenvolvimento de novas habilidades que extrapolam o aprendizado do conteúdo almejado. Nessa dinâmica, constrói-se um campo ideal para a inovação, uma das principais características de todo o processo. Aprender a mudar a dinâmica do processo de ensino-aprendizagem tradicional requer criatividade, uso de todas as ferramentas possíveis que estimulem e possibilitem um contexto fluido para a aquisição e difusão de conhecimento. Construir novas metodologias é um dos princípios que norteiam as metodologias ativas.

Por fim, a mudança do papel do professor está inserida nos princípios, talvez um dos mais desafiadores, das metodologias ativas. A ideia de construir um professor mediador/facilitador requer a quebra de barreiras profundas na própria formação docente. Nos moldes tradicionais de educação, o professor é estimulado, ao longo de suas formações, a entender que ele é o principal agente em todo o processo. Com isso, ele continua detendo o poder do conhecimento e o de ensinar, mesmo com as mudanças de perspectiva acerca da didática empreendidas nas últimas décadas e a descentralização das fontes do saber: dos livros impressos para um universo textual de múltiplas tipologias, acessado virtualmente. Ainda assim, o caráter do professor transmissor continua bastante vigente no nosso contexto educacional. Contudo, no ideário das metodologias ativas, ensinar significa "provocar, desafiar ou ainda promover as condições de construir, refletir, compreender, transformar, sem perder de vista o respeito à autonomia e à dignidade deste outro" (Diesel et al. 2017: 278).

Dentre as diversas metodologias ativas existentes, a problematização com arco de Maguerez atendia, com maior veemência, às especificidades do nosso estudo de caso, sobretudo no caráter intervencionista almejado ao final de todo o processo. Tal característica estava muito mais coerente com a realidade próxima ao cotidiano dos alunos envolvidos nas oficinas. A escolha ainda levava em consideração as condições reais de tempo, do local e do nível de aprendizado prévio dos alunos e de suas participações efetivas (Fig. 1). 


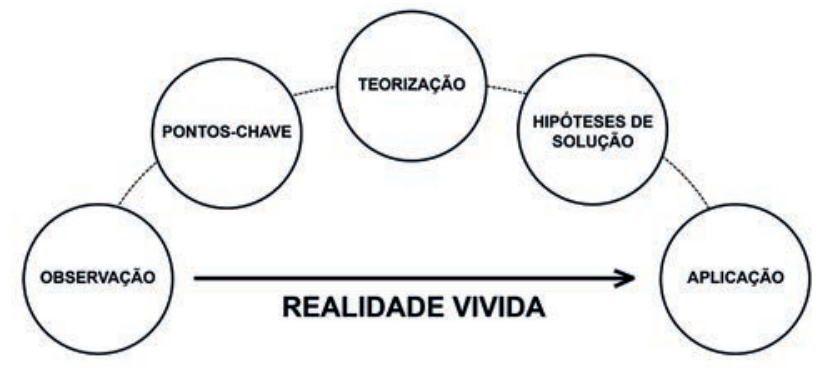

Figura 1. Arco de Maguerez. Fonte: Bordenave, J. e Pereira, 2005.

\section{Realidade vivida}

O objeto de estudo escolhido para a aplicação da arqueologia da arquitetura para reconhecimento, valorização e registro do patrimônio edificado dentro da realidade vivida pelos alunos de ambos os cursos surgiu por convite do Instituto do Patrimônio Histórico e Artístico Nacional (IPHAN), Superintendência de
Sergipe. O IPHAN solicitou participação da universidade nos estudos prévios para a restauração da ruína da "Casa n. 3" (Fig. 2), objeto situado em local privilegiado do centro histórico da cidade de Laranjeiras e que sofreria intervenções demandadas por instâncias do Poder Judiciário.

Cabe mencionar que Laranjeiras se configurou, na construção do imaginário sergipano, como o berço das manifestações culturais, fruto da herança dos diversos povos de origem africana, escravizados e utilizados como mão de obra em todo o ciclo produtivo do açúcar. A história da construção material da cidade está intimamente ligada a esse importante ciclo econômico nacional. Grande parte do casario e dos edifícios comerciais, hoje em ruínas, experimentou seu auge construtivo no apogeu da produção açucareira do estado de Sergipe e, por isso, o seu desenvolvimento não pode ser desvinculado das propriedades e do enredo social dos engenhos que circundam a cidade (Santos 2003).

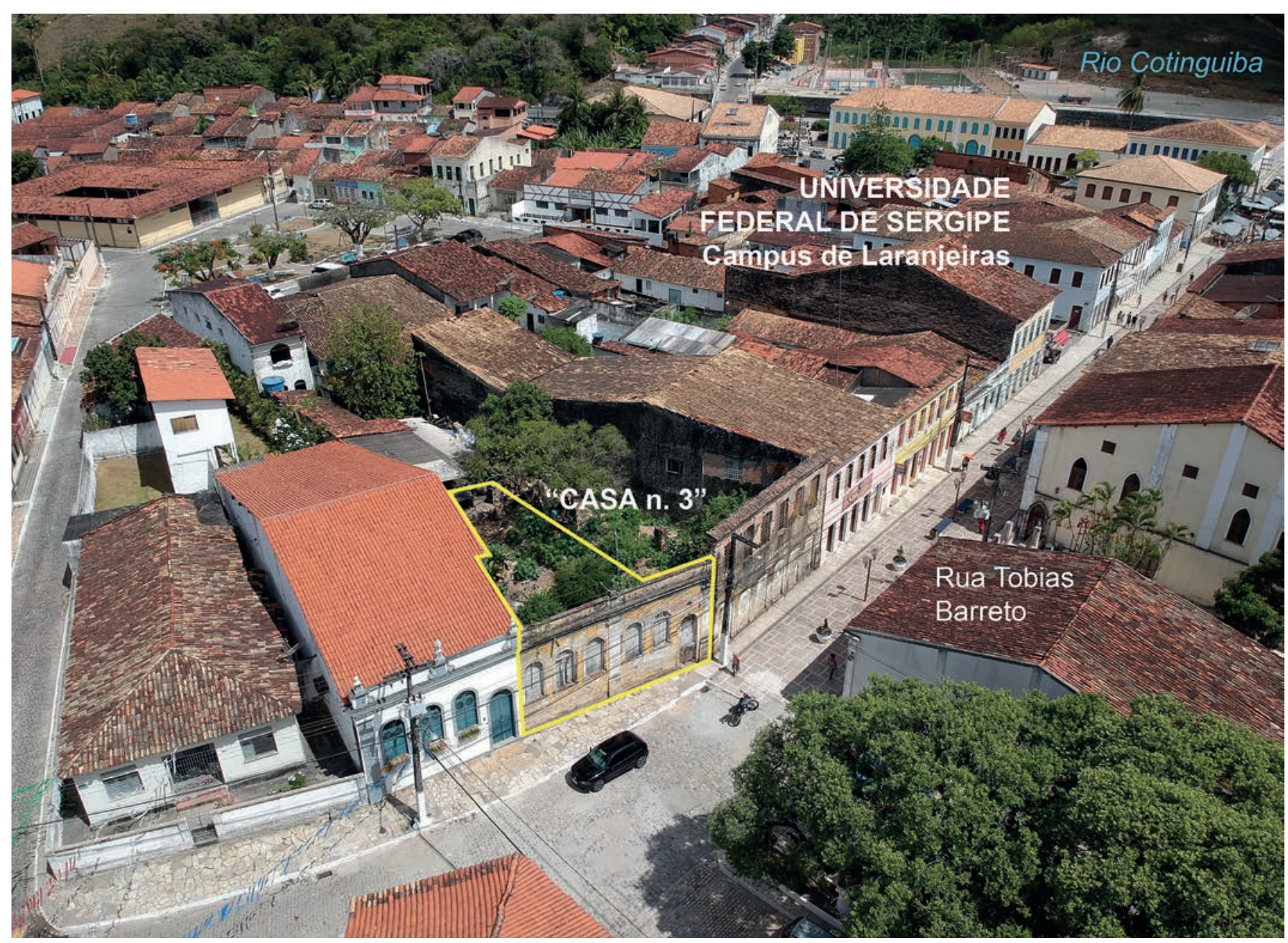

Figura 2. Fotografia aérea de Laranjeiras, Sergipe. Em primeiro plano, lote da "Casa n. 3"; ao fundo, sede do Campus da Universidade Federal de Sergipe. Fonte: Oficina de Projetos, inscrição dos autores, 2019. 
O desenvolvimento da indústria açucareira tardia, em relação à Bahia e a Pernambuco, provocou um aumento considerável da construção de engenhos e dos pontos de suporte comercial junto às cidades e aos povoados que margeavam o rio Cotinguiba, rio que margeia também Laranjeiras. No ano de 1798, Sergipe possuía 140 engenhos, ao passo que, em 1856, totalizavam 750 . No auge da economia açucareira, Laranjeiras e Maruim eram consideradas as mais prósperas cidades sergipanas. "O desenvolvimento de um e de outro município ocorrera paralelamente ao crescimento da economia do açúcar, e de simples vilas na primeira metade do século XIX, tornaram-se importantes cidades, residência dos políticos" (Amaral 2007: 34).

\section{Observação}

Eleito o objeto de estudo, o segundo passo, no desenvolvimento das atividades propostas, foi começar a entender a perspectiva dos alunos sobre o patrimônio da cidade. Cabe mencionar que alguns deles residem no próprio município; outros o frequentam em função da presença da universidade, que também se encontra no centro histórico. As oficinas foram, inicialmente, instrumentalizadas pela divisão dos alunos em grupos de 10 pessoas, reunidas em sessões de tutoria para discutir e tomar decisões sobre o procedimento a ser tomado pelo grupo em cada etapa que constitui o arco (Fig. 3).

Após processo de sociabilização, foram apresentadas as ruínas e, após visita, realizada uma segunda sessão para que se pudesse observar a realidade. Importante salientar que a intervenção corresponde a um real caso, envolvendo IPHAN, empresa de arquitetura, comunidade e universidade. Num primeiro momento, aos alunos de arqueologia, foi difícil observar a complexa rede de relações. Tratava-se de uma ruína, cuja família teria acionado o Ministério Público com a justificativa de que o IPHAN deveria arcar com a restauração do imóvel. Aos alunos de arquitetura, a questão nem mesmo se colocava, pois o interesse permanecia na compreensão genérica da ruína no espaço da cidade, de modo que foi notória a dificuldade de compreendê-la do ponto de vista material.

Como resultado das observações, ficou evidente a grande lacuna na percepção dos alunos sobre a atuação do órgão de preservação, da mesma maneira que se constatou a larga distância operacional entre a legislação patrimonial e a complexidade da realidade vivida. Ainda

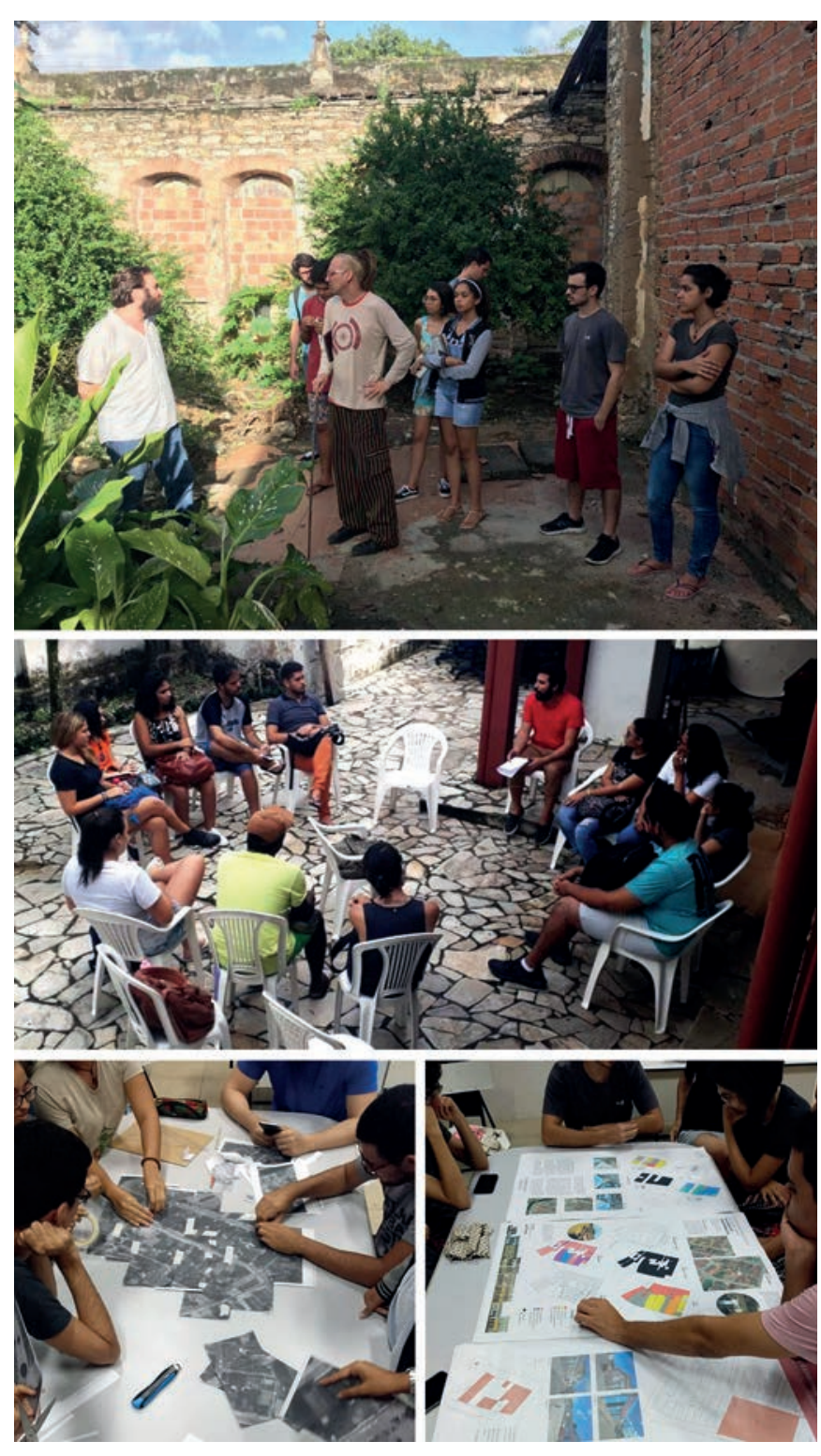

Figura 3. Visita ao objeto de estudo e discussão, com a produção de mapas para análise da realidade vivida. Autor: Pedro Freitas.

é importante frisar que essa dinâmica ampliou entre os futuros arqueólogos a compreensão acerca da instituição: anteriormente como punitiva e ineficaz, passou a ser percebida como um órgão com necessidades operacionais evidentes em diversas esferas preservacionistas. Aos futuros arquitetos, para além desse debate, por iniciativa do grupo formado, estimulou-se a compreensão das quadras do entorno imediato ao objeto de estudo, visando a suplantar as dificuldades operativas relativas à falta de desenhos sobre o espaço edificado, gerando-se os primeiros cadastros físicos urbanos (Fig. 4). 


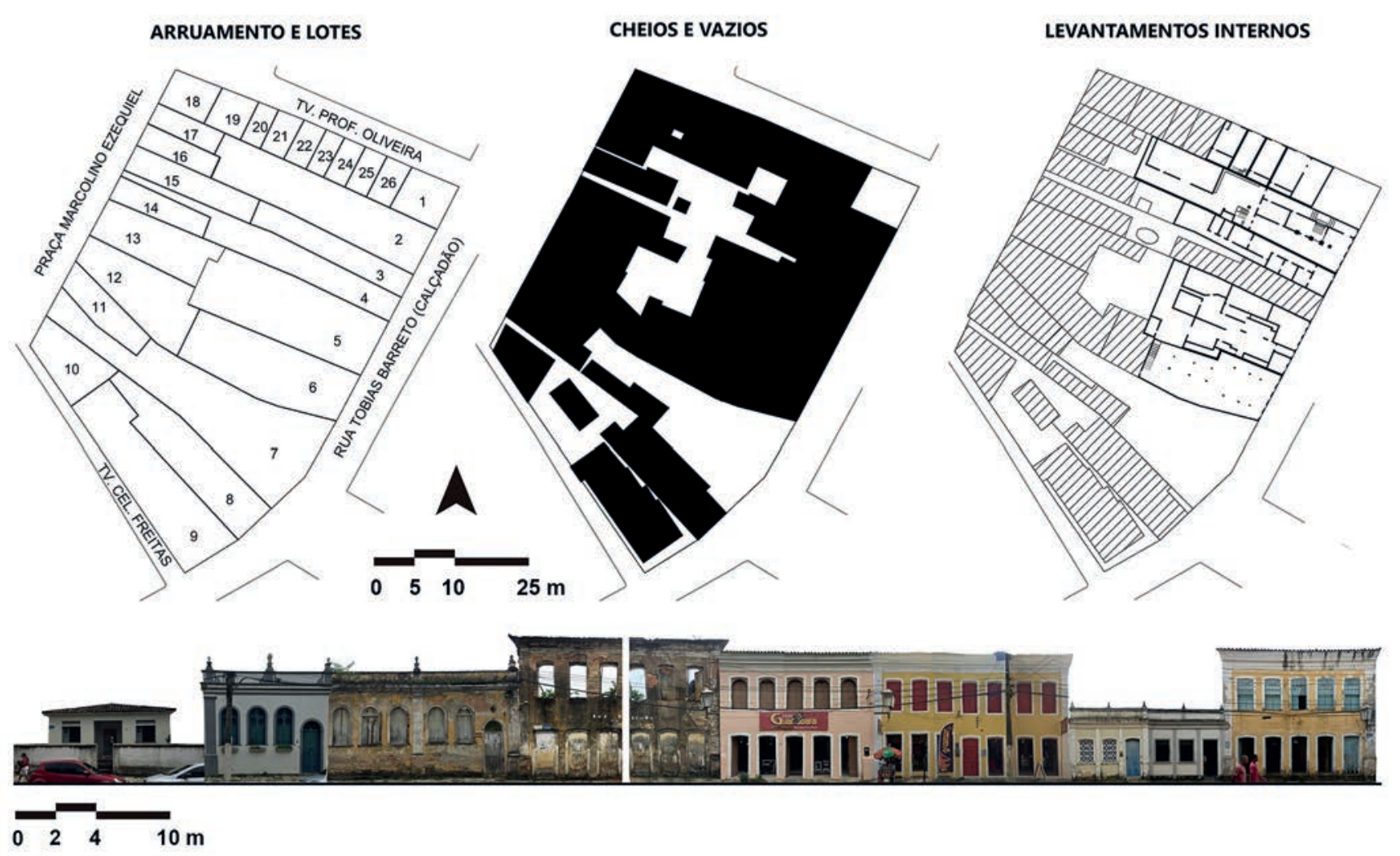

Figura 4. Mosaico ortofotográfico das fachadas da quadra e levantamento do entorno imediato do objeto de estudo. Desenhos: Natália Guimarães, Emilly Silva e Daniela Santos (graduandas AU/UFS).

\section{Pontos-Chave}

A segunda rodada de sessões tutoriais objetivou ampliar a observação da realidade para se definir quais seriam os pontos-chave da problemática. Tais pontos deveriam ser suficientemente direcionados e afunilados para tratar especificamente de questões patrimoniais vinculadas ao objeto de estudo. Em outras palavras, os alunos deveriam chegar ao consenso, através das discussões, sobre quais seriam as questões mais importantes diante do cenário de atuação possível. Os principais pontos definidos pelo grupo foram:

a) descompasso entre demandas sociais e gestão do patrimônio;

b) baixo conhecimento sobre o imaginário da população em relação às ruínas;

c) desconhecimento das técnicas construtivas da arquitetura local;

d) fragilidade das pesquisas históricas associadas aos estudos prévios e às intervenções de conservação e restauro; e) projetos de intervenção sem o devido conhecimento sobre a materialidade construtiva.

\section{Teorização}

$\mathrm{Na}$ fase de teorização, os alunos deveriam pensar acerca dos conhecimentos necessários para atuar sobre a realidade observada. No caso das ruínas da Casa n. 3, era necessário refletir sobre quais conhecimentos orientariam a prática de um arqueólogo e um arquiteto. Nessa fase, a participação dos professores foi mais efetiva no sentido de apresentar para os alunos um amplo leque de possibilidades. Contudo, era deles a decisão do que deveríamos estudar. Nessa perspectiva, foram realizados: minicurso de desenho, levantamento e prática de cadastro fotogramétrico, com o professor Pedro Freitas, do Departamento de Arquitetura e Urbanismo (DAU/UFS); uma oficina sobre legislação arqueológica, com a arqueóloga do IPHAN, Beijanize Abadia; uma oficina sobre georadar aplicado à arqueologia, com o professor Antonio Garcia, do Departamento de Geologia (DGEO/UFS); uma oficina sobre leitura estratigráfica em arqueologia da arquitetura, com o professor Ton 
Ferreira, do Departamento de Arqueologia (DARQ/UFS), e uma segunda oficina sobre patologias da construção, com o professor Pedro Freitas, do DAU/UFS (Fig. 5).

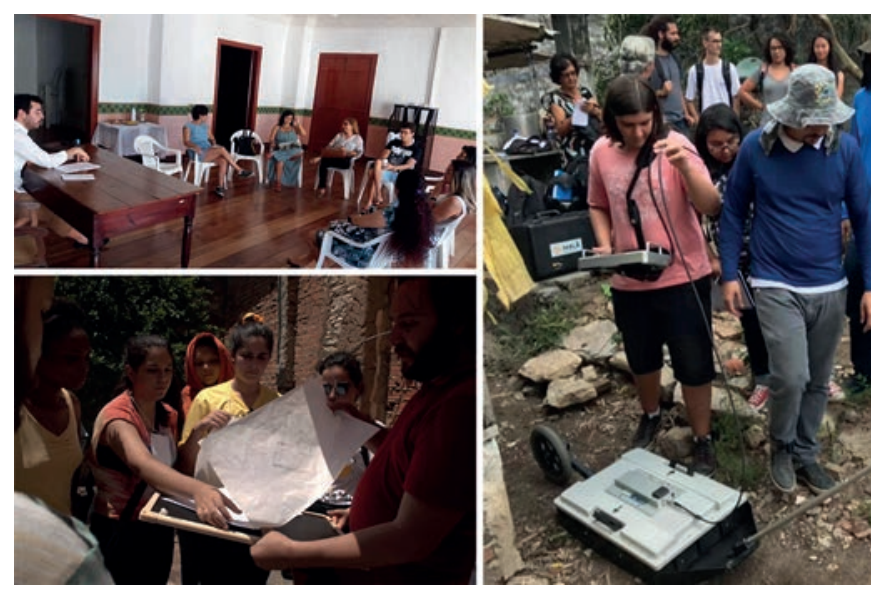

Figura 5. Oficinas de teorização. Autor: Ton Ferreira.

\section{Hipóteses de solução}

Numa última rodada de sessões tutoriais, foram decididas quais seriam as soluções para a atuação. Em suma, indagamos quais as resoluções e ações requeridas de arqueólogos e arquitetos nessa fase de exame prévio à intervenção. Levando em consideração todos os pressupostos teóricos da restauração arquitetônica, a produção da arqueologia brasileira e os pressupostos metodológicos da AA, assumimos como metodologia de intervenção:

a) inserção da leitura estratigráfica nos moldes metodológicos da AA;

b) utilização da arqueometria aplicada aos materiais construtivos;

c) identificação e registro dos materiais e técnicas construtivas;

d) escavação arqueológica das áreas internas e externas das ruínas, após discussão com a empresa responsável, a fim de direcionar as escavações para os problemas da conservação e restauro do bem;

e) pesquisa histórica de fontes primárias, nos arquivos do judiciário e público do estado de Sergipe;

f) entrevista com moradores locais, para identificar as narrativas construídas em torno das ruínas da Casa n. 3, assim como entender a sua percepção sobre essas; g) levantamento dos diversos significados da edificação ao longo de sua existência e seus usos na dinâmica da construção da sociedade local.

\section{Aplicação}

A fase de aplicação ocorreu no último mês do período letivo, depois das últimas sessões tutoriais de cada disciplina. As intervenções arqueológicas em solo requereram análise do projeto por parte do IPHAN e posterior emissão de portaria de pesquisa no Diário Oficial da União. Como exercício, os alunos de arqueologia foram estimulados a construir um projeto de pedido de portaria em equipe para que pudessem experimentar a relação com o órgão, que balizará a sua atuação profissional futura. Nessa fase, aos alunos de arquitetura, exercícios projetuais de especulação de propostas de intervenção foram estimulados a fim de fazê-los compreender tanto trabalhos referenciais como as possíveis limitações físicas existentes ao se trabalhar na arquitetura existente com importância cultural.

As primeiras atividades centraram-se na leitura estratigráfica das faces interna e externa da ruína, identificando as unidades, realizando tanto o devido preenchimento dos instrumentos de coleta de dados como os desenhos necessários. Nessa etapa, foi fundamental entender a importância do real registro (Fig. 6) e da percepção da materialidade construtiva, especificamente quando se comparavam levantamentos anteriores sobre os mesmos objetos e se constatava a falta de informação suficientes.

Após tais levantamentos, foram realizados dez dias de campo ininterruptos para a escavação interna das ruínas (Fig. 7). Nessa etapa, foram evidenciados pisos, frutos das alterações do imóvel no decorrer da sua existência, estruturas de paredes desabadas, restos de lixo cotidiano dos antigos moradores, assim como dos atuais, além de se evidenciar todo o processo de desestruturação da materialidade construtiva até se chegar ao estágio atual do objeto histórico. Alunos do curso de arquitetura e urbanismo não integrantes do projeto foram também estimulados a visitar o campo durante a Semana de Arquitetura e Urbanismo, organizada no mesmo período pelo centro acadêmico, ampliando o impacto das atividades de pesquisa. Tal dedicação, posteriormente, também se estendeu entre os arquitetos participantes, para a análise dos danos das fachadas das demais ruínas da rua, a fim de ampliar o espectro de estudos e potencializar práticas integradas de intervenção física. 


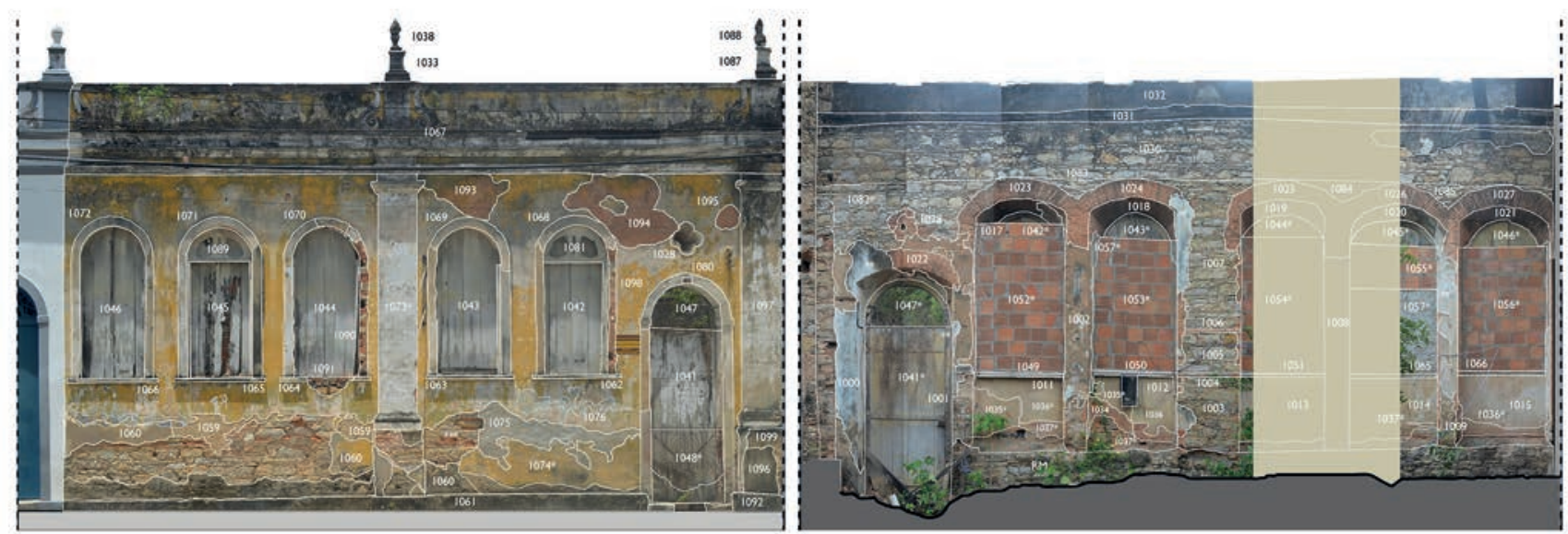

Figura 6. Mosaico ortofotográfico das faces interna e externa da fachada principal da "Casa n. 3", com análise preliminar das unidades estratigráficas realizadas em conjunto com os alunos. Síntese: Ton Ferreira (DARQ-UFS). Desenho: Pedro Freitas (DAU-UFS).
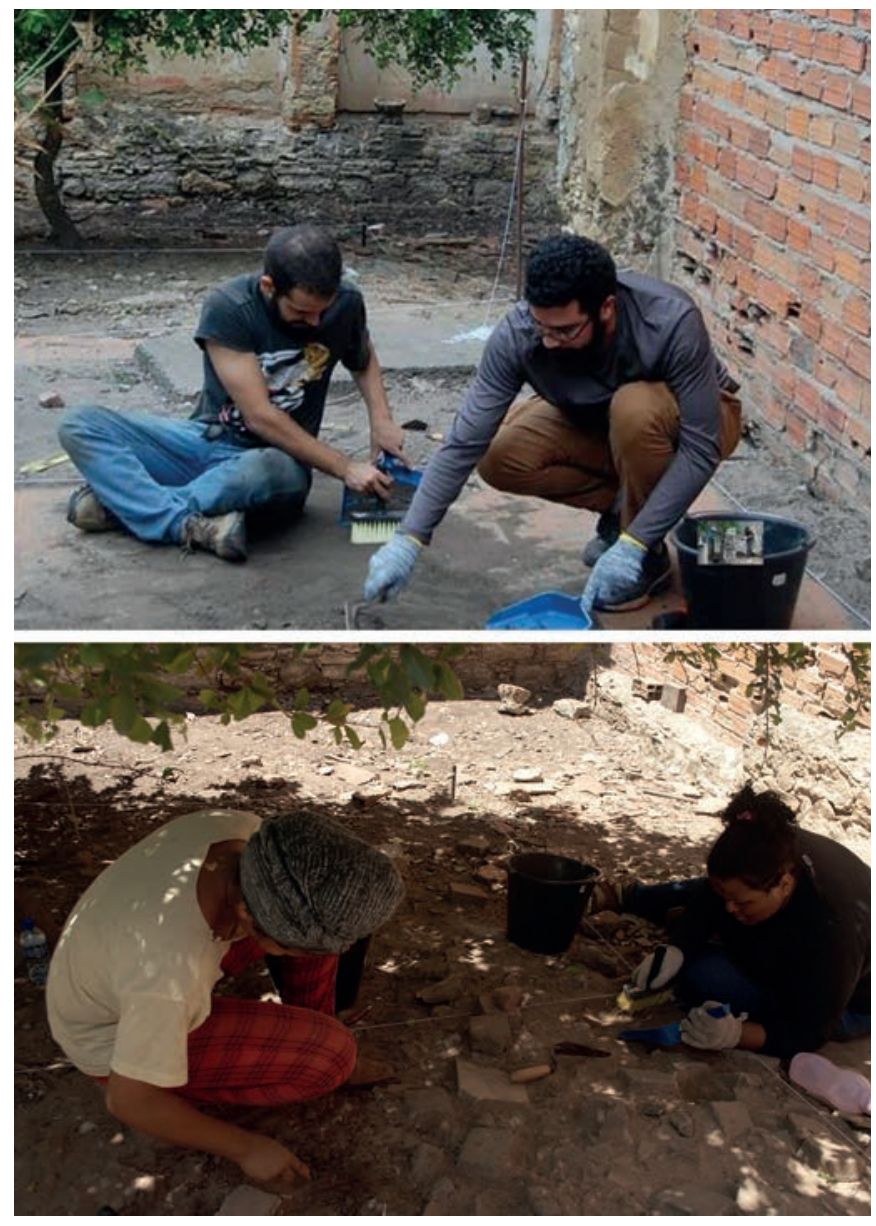

Figura 7. Atividades de campo. Autor: Vitor Araujo.

Todos os dados da etapa de campo ainda precisam ser ainda analisados em laboratório, para uma completa apreensão do cotidiano vivido nesse espaço. Está ainda prevista nova etapa de campo, consolidação das entrevistas com moradores e ampliação da pesquisa arquivística e bibliográfica. Ademais, entre os alunos de arqueologia, dúvidas iniciais sobre a configuração dos espaços internos, bem como a transformação de uma casa térrea em duas, foram sanadas ao já se vincularem as informações da leitura estratigráfica das paredes às informações do solo (Fig. 8a). Entre os alunos de arquitetura, as propostas finais apresentadas (Fig. 8b), ainda que decorrentes de um tradicional exercício projetual especulativo, foram realizadas com maior segurança pois não estavam desvinculadas da realidade - questão comum aos tradicionais "ateliês de projeto" do curso. Em outras palavras, critérios de base arqueológica adquiridos no decorrer do estudo foram fundamentais, atingindo objetivos propostos de formação. Nesse sentido, os resultados, ainda que preliminares para ambas as disciplinas, já extrapolam qualquer atividade docente desenvolvida no âmbito das cadeias curriculares tradicionais de ambos os cursos.

Com o desenvolvimento das atividades aqui mencionadasduas constatações importantes podem ser aventadas. A primeira delas diz respeito à importância da leitura estratigráfica murária como possibilidade de entendimento construtivo, ao analisar as suas relações, mas também como forma de registro da materialidade construtiva. Os levantamentos arquitetônicos realizados não foram suficientes para identificar técnicas construtivas ainda desconhecidas. Muitos detalhes foram suprimidos por ferramentas de desenhos do AutoCAD, que mascaram a realidade construtiva; nesse sentido, perdem-se detalhes e, com eles, uma infinidade de significados e adaptações construtivas locais. A segunda constatação diz respeito às escavações de solos, as intervenções revelaram estruturas e configurações do espaço cujo projeto arquitetônico inicial, antes da nossa participação no projeto, não havia identificado. 

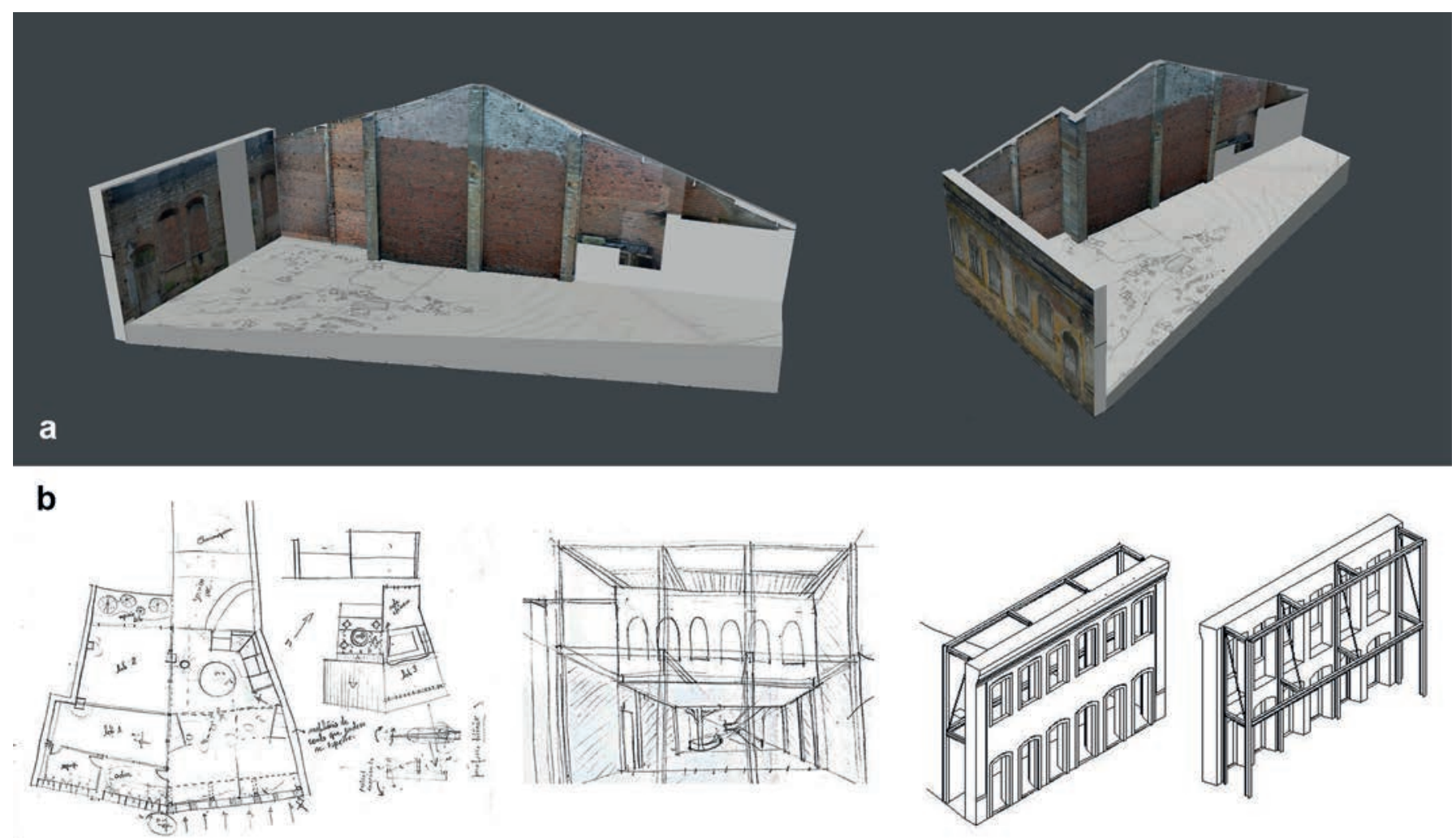

Figura 8. Resultados preliminares: a) modelo tridimensional para nova interpretação dos dados coletados, incluindo fachada lateral e primeira documentação do material de solo escavado. Desenho: Pedro Freitas (DAU-UFS); b) exercícios exploratórios de projeto arquitetônico para adaptação do conjunto edificado a novos usos. Desenhos: Igor Santos (graduando AU/UFS).

Para além das perdas de recursos e de tempo, decorrentes da falta de estudos arqueológicos adequados antes da construção do projeto, ao prescindirmos um olhar mais amplo sobre o processo de restauro, estamos destruindo a possibilidade de entrarmos em contato com materiais, técnicas e com configurações de espaços que podem revelar muito sobre o nosso passado. A homogeneização estilística das edificações brasileiras como modelos europeus adaptados não apenas esconde o caráter arquitetônico local, como também elimina indivíduos, sociedades que tiveram uma papel importante na configuração da sociedade brasileira.

\section{À GUISA DE CONCLUSÃO}

As primeiras abordagens da arqueologia brasileira sobre o patrimônio edificado sempre estiveram ligadas aos estudos das suas fundações e análises de seus artefatos. As parcas intervenções sobre as paredes, quando existiam, eram motivadas pela busca de modificações de fechamento de portas e janelas, ou mesmo de modificações nas configurações de cômodos. Na última década, a abordagem teórica pós-processual, sob o signo de arqueologia da arquitetura, tem produzido importantes estudos sobre os significados dos espaços construídos da arquitetura contemporânea. No entanto, esses mesmos estudos ainda carecem de aportes metodológicos sistemáticos para o registro e a análise da materialidade construtiva da edificação histórica.

Somente com os programas públicos de revitalização, a discussão sobre a real contribuição da arqueologia nos estudos prévios à construção do projeto de restauro passou a ser posta em evidência pelos arquitetos e arqueólogos envolvidos nos projetos. Tais embates foram fundamentais para o entendimento de que as lacunas advinham do processo de formação de ambos os profissionais. Se, por um lado, arqueólogos não abordavam sistematicamente as paredes históricas, por outro, arquitetos não viam nos estudos da materialidade preexistente um fio condutor para a construção do projeto de restauro.

Dessa forma, ao refletirmos sobre limites e possibilidades da transferência da AA nos moldes europeus para a realidade brasileira, verificamos como a disciplina ainda é um importante aporte para as nossas lacunas no que se refere aos estudos prévios à restauração arquitetônica. É justamente nesse âmbito que ela pode dar maior contribuição, seja nas suas metodologias de 
leitura estratigráfica murária, nos estudos da materialidade construtiva e técnicas tradicionais ou mesmo na simples documentação de uma série de exemplares da arquitetura vernácula em processos de desaparecimento.

Acreditamos também que a inclusão dos métodos da AA para estudo da materialidade construtiva ainda deva complementar os estudos já realizados em solo, pela chamada arqueologia histórica. $\mathrm{O}$ arcabouço teórico e analítico até então construído deve ser inserido e ampliado com um maior controle sobre a materialidade construtiva vertical, até então ignorada. Embora distante desse domínio, é preciso salientar que a arqueologia histórica construiu um importante legado interpretativo sobre os usos dos espaços edificados. Foi possível narrar cotidianos antigos cujas fontes documentais não eram capazes de acessar. Descreveram-se a perversão criativa dos usos dos espaços e as diversas adaptações do modo de vida forjadas no bailar do hibridismo cultural que se projetou num novo continente em construção. Tais estudos puderam construir pistas sobre a intimidade de grande parcela da sociedade, invisível pelas nuances do sistema patriarcal. Essas são apenas algumas das contribuições que os estudos arqueológicos sobre os espólios associados ao patrimônio histórico americano puderam evidenciar nas últimas décadas.

Assim, embora considerando em andamento as atividades realizadas, cujos resultados ainda estão por se consolidar em futuras publicações, a experiência confirmou que estamos diante de um desafio que somente poderá ser parcialmente solucionado através de uma nova geração de arqueólogos e arquitetos que entendam o processo de construção do conhecimento interdisciplinar. Isso ficou evidente conforme foi se transformando a percepção dos alunos envolvidos no momento auge das atividades propostas: a aplicação sobre a realidade observada e teorizada. Nessa fase, as perspectivas construídas durante, aproximadamente, quatro meses - no âmbito de cada disciplina - foram revisadas: desde desilusões concernentes à relação entre o conhecimento bibliográfico e o exercício da prática profissional às lacunas e aos problemas da práxis profissional não descritas nos livros. Permitiu-se, portanto, compreender a razão das soluções improvisadas e que não aparecem nas edições dos manuais de ambas as profissões.

\section{BIBLIOGRAFIA}

Albuquerque, M. 1980: "Escavações arqueológicas realizadas na igreja quinhentista de Nossa Senhora da Divina Graça, em Olinda”, Revista Clio, 3, pp. 89-90.
Albuquerque, M. 1992: "Arqueologia Histórica, Arquitetura e Restauração", Revista Clio, 8, pp. 131-151.

Amaral, S. P. 2007: Escravidão, liberdade e resistência em Sergipe: Cotinguiba 1860-1888. Universidade Federal da Bahia, Salvador.

Araujo, A. G. M. 2011: "Resenha- Geoarqueologia de um Sambaqui Monumental - estratigrafias que falam”, Revista Habitus, 9, 1, pp. 213-217.

Barreto, C. 1999: "Arqueologia Brasileira: uma perspectiva histórica e comparada", Revista do Museu de Arqueologia e Etnologia, Suplemento 3, pp. 201-212.

Berbel, N. A. N. 2014: "Metodologia da problematização: respostas de lições extraídas da prática", Semina, 35, pp. 61-76.

Bordenave, J. e Pereira, A. 2005: A estratégia de ensino-aprendizagem (26 ${ }^{\mathrm{a}}$ ed.).Vozes. Petrópolis.

Brasil. Lei n. 3.924 de 26 de Julho de 1961: Dispõe sobre os monumentos arqueológicos e pré-históricos. Diário Oficial da União, Rio de Janeiro.

Brasil. Programa Monumenta. 2006: Programa de preservação do patrimônio histórico urbano. Regulamento Operativo 1200/OC-BR. Brasília.

Camargo, M. J. 2015: "Depoimento do professor Nestor Goulart Reis Filho", Revista CPC, 20, pp. 261-280.

Carbonara, G. C.; B. P. Torsello; et al. 2005: Che cos'è Il restauro: nove studiosi a confronto. Marsilio, Venezia.

Corona, E. e Lemos, C. 1973: Dicionário da Arquitetura Brasileira. Edart, São Paulo.

Costa, T. C. 2013: A arqueologia como instrumento de preservação do patrimônio arquitetônico: a restauração do Quarteirão dos Trapiches de Laranjeiras/SE. Universidade Federal de Sergipe, Laranjeiras.

Davini, M. C. 2009: Currículo integrado. Folhetos, São Paulo.

Diesel, A.; Baldez, A. L. S. e Martins, S. N. 2017: "Os princípios das metodologias ativas de ensino: uma abordagem teórica”, Revista Tema, 14 pp. 286288.

Doglioni, F. 1988: "La Ricerca sulle strutture edilizie tra archeologia stratigrafica e restauro architettonico", en R. Francovich e R. Parenti (org.), Archeologia e Restauro dei monumenti. I ciclo di lezioni sulla ricerca applicata in archeologia, pp. 223-24. Firenze.

Fonseca, M. C. L. 2005: O patrimônio em processo: trajetória da política federal de preservação no Brasil. Editora UFRJ/MinC-Iphan, Rio de Janeiro.

Freire, P. 2002: Pedagogia da autonomia. Paz e Terra, Rio de Janeiro.

Johnson, M. 1999: Archaeological Theory: an introduction. Blackwell Publishers, Malden - Oxford

Lima, T. A. 1993: “Arqueologia Histórica no Brasil: balanço bibliográfico (1960-1991)", Anais do Museu Paulista, 1, pp. 225-262.

Mannoni, T. e Milanese, M. 1988: "Mensiocronologia" en R. Francovich e R. Parenti, Archeologia e Restauro dei Monumenti, pp. 383-402. Firenze.

Mileto, C. e Vegas, F. 2003: "El análisis estratigráfico constructivo como estudio previo al proyecto de restauración arquitectónica: metodología y aplicación", Arqueología de la Arquitectura, 2, pp. 189-196.

Najjar, R. 2002: Manual de Arqueologia Histórica em Projetos de Restauração. IPHAN, Brasília.

Organização dos Estados Americanos. 1967: Normas de Quito. IPHAN, Brasília.

Santos, J. F. 2003: Do fausto às ruínas: subsidios para a exploração arqueológica do Engenho Ilha, Laranjeiras-SE. Universidade Federal de Sergipe, São Cristóvão.

Santos, J. F. 2011: La búsqueda de bases metodológica para la intervención arqueológica en la restauración arquitectónica - el caso Brasil. Universidad Autónoma de Madrid, Madrid.

Tirello, R. A. 1999: "Um trabalho arqueológico: A descoberta das pinturas parietais de uma velha casa no Bexiga", en Comissão de Patrimônio Cultural da USP (org.), A Casa de D. Yayá, pp. 101-131. Edusp/ Imprensa Oficial, São Paulo.

Tirello, R. A. 2002: “O restauro dos murais Art Nouveau da Vila Penteado e o Canteiro Escola da CPC USP: uma experiência de formação qualificada", en M. L. R. R. Martins (org.), Vila Penteado 1902-2002, pp. 239-268. FAU USP, São Paulo. 
NA RESTAURAÇÃO ARQUITETÔNICA NO BRASIL

Tirello, R. A. 2007: "A Arqueologia da Arquitetura: um modo de entender e conservar edifícios históricos”, Revista CPC, 3, pp.145-165.

Villagran, X. S. 2010: Geoarqueologia de um Sambaqui Monumental - estratigrafias que falam. Annablume, São Paulo.

Zarankin, Andrés. 2001: Paredes que domesticam: Arqueologia da Arquitetura Escolar Capitalista: O caso de Buenos Aires. Tese de doutorado, Universidade de Campinas.
Zarankin, A. e Niro, C. 2008: "A materialização do sadismo: arqueologia da arquitetura dos Centros Clandestinos de Detenção da ditadura militar argentina (1976-83)", in P. P. Funari, A. Zarankin e J. A. Reis, Arqueologia da repressão e da resistência: América Latina na era das ditaduras (décadas de 1960-1980). Annablume, São Paulo. 